Article

\title{
Characteristics of Dissolved Organic Matter and Its Role in Lake Eutrophication at the Early Stage of Algal Blooms-A Case Study of Lake Taihu, China
}

\author{
Shuhang Wang ${ }^{1,2}$, Wenwen Wang ${ }^{1,2,3}$, Junyi Chen ${ }^{1,2}$, Bo Zhang ${ }^{1,2}$, Li Zhao ${ }^{1,2}$ and \\ Xia Jiang $1,2,3, *$ \\ 1 National Engineering Laboratory for Lake Pollution Control and Ecological Restoration, Chinese Research \\ Academy of Environmental Sciences, Beijing 100012, China; wangsh@craes.org.cn (S.W.); \\ 201631470012@mail.bnu.edu.cn (W.W.); beyond8090@163.com (J.C.); zhangbo@craes.org.cn (B.Z.); \\ zhao.li@craes.org.cn (L.Z.) \\ 2 State Environment Protection Key Laboratory for Lake Pollution Control, Chinese Research Academy of \\ Environmental Sciences, Beijing 100012, China \\ 3 College of Water Sciences, Beijing Normal University, Beijing 100875, China \\ * Correspondence: jiangxia@craes.org.cn; Tel.: +86-010-84913896
}

Received: 27 June 2020; Accepted: 11 August 2020; Published: 13 August 2020

\begin{abstract}
Decaying algal blooms in eutrophic lakes can introduce organic matter into the water and change nutrient concentrations in the water column. The spatial distribution and composition characteristics, sources, and contribution to eutrophication of dissolved organic matter (DOM) in the overlying water of Lake Taihu, a typical eutrophic lake in China, were analyzed by ultraviolet-visible spectra and three-dimensional fluorescence excitation-emission matrix spectra combined with the statistical decomposition technique, parallel factor analysis. The concentration of DOM was represented by dissolved organic carbon (DOC), and DOC in overlying water of Lake Taihu was $2.86-11.83 \mathrm{mg} / \mathrm{L}$. The colored DOM (CDOM) was characterized by an absorption coefficient at $280 \mathrm{~nm}$ $\left(a_{280}\right)$ and $350 \mathrm{~nm}\left(a_{350}\right)$, which were 6.63-29.87 and 1.84-10.41 $\mathrm{m}^{-1}$, respectively. These values showed an increasing trend from southeast to northwest, and the high values were concentrated in the northwest and northern lake areas. The parallel factor analysis (PARAFAC) identified two protein-like (C1: tyrosine-like and C2: tryptophan-like) and one humic-like (C3: humic acid and fulvic acid) fluorescence components for fluorescent DOM (FDOM). The most dominant components were protein-like components $(\mathrm{C} 1+\mathrm{C} 2)$, whose fluorescence intensity contributed $87.55 \% \pm 3.39 \%$ to the total fluorescence intensity $\left(F_{t}\right)$ of FDOM (3.38 R.U.). The mean value of the fluorescence index (FI) and index of recent autochthonous contribution (BIX) of DOM was 1.77 and 0.92, and DOC, $a_{280}$ and fluorescence intensities of FDOM components were all significantly and positively correlated with chl. $a$, indicating that DOM, CDOM, and FDOM were all mainly derived from algal activities and metabolites. The average humification index of the DOM was 0.66 , which indicated a low humification degree. The protein-like DOM was correlated with DON and DOP, and might make great contributions to the continuous occurrence of algal blooms.
\end{abstract}

Keywords: algal-derived DOM; fluorescence component; source; algal bloom; lake eutrophication

\section{Introduction}

Dissolved organic matter (DOM) is a kind of organic matter composed of heterogeneous structures and compositions [1]. DOM is widely found in rivers, lakes, and other natural aquatic environments, and plays an important role in aquatic ecosystems [2,3]. DOM contains a variety of functional groups, such as aliphatic, aromatic, quinine, and phenolic groups [4]. These functional groups can combine with 
organic and inorganic pollutants, change their distribution at the water-sediment interface, enhance their solubility and mobility in water, and thus affect their biological effectiveness and toxicity [5-7]. The composition of DOM has an important impact on its role in the environment. Colored dissolved organic matter (CDOM) refers to the colored DOM in water and is the main light-absorbing component of natural water [8,9]. CDOM can effectively absorb ultraviolet radiation and protect aquatic organisms from harmful radiation $[10,11]$. CDOM can decompose from macromolecular OM into small-molecule $\mathrm{OM}$ and inorganic nutrients after photochemical degradation, and creates favorable conditions for the growth of microbes and phytoplankton [12-14]. Fluorescent DOM (FDOM) refers to the CDOM component that can emit fluorescence after absorbing ultraviolet and visible light [15-17]. Relevant studies [18-21] have shown that, in specific regions and seasons, the ratio of CDOM to dissolved organic carbon (DOC) is constant and a good correlation exists between the two types of organic matter (OM).

DOM in water has a wide range of terrestrial and autochthonous sources [22,23]. Terrestrial sources mainly include soil leaching, surface runoff, and industrial and domestic sewage discharge [24,25]. Autochthonous sources mainly include the activities and metabolites of microorganisms and algae, decomposition of aquatic plants, and release of sediments [24,26]. Compared with DOM from terrestrial sources, DOM generated from autochthonous sources is rich in carbohydrates, easily degradable, and can participate in the migration and transformation of matter and energy transfer in the food chain, thereby making significant contributions to primary productivity [27]. For eutrophic lakes with frequent algal blooms, a large proportion of DOM can be produced as a result of these algal blooms and associated microbial assemblages, leading to increased DOM concentration in the water column [1]. The algal-derived DOM may change the occurrence characteristics and environmental behaviors of $\mathrm{N}$ and $P$ in aquatic environments and exert an important effect on lake eutrophication. Therefore, studies on the occurrence characteristics, migration, and transformation of DOM in aquatic environments and its relationship with $\mathrm{N}$ and $\mathrm{P}$ during algal bloom outbreaks in eutrophic lakes are important in the management of lake eutrophication.

Lake Taihu is a typical eutrophic lake in the world. The algal blooms in Lake Taihu usually happen during May to October and seriously affect the ecological function of the lake. Previous studies have shown that the concentration of CDOM in Lake Taihu is high, and the high CDOM poses a threat to the water quality and safety of the lake $[28,29]$. There have been several previous studies on the influence of algal bloom on DOM in Lake Taihu [1,30], but few studies on the occurrence characteristics of DOM at the early stage of algal bloom.

To explore the occurrence characteristics of DOM and the role it plays in the early stage of algal blooms in Lake Taihu, spatial distribution, composition, and sources of DOM in the overlying water of Lake Taihu at the early stage of algal blooms were investigated by combination use of ultraviolet-visible (UV-Vis) spectra, fluorescence excitation-emission spectra (F-EEMs), and parallel factor analysis (PARAFAC) methods. The relationships between the fluorescence characteristic index of DOM and the important indicators of eutrophication, such as N, P, and chlorophyll a (chl. $a$ ), were also analyzed.

\section{Materials and Methods}

\subsection{Study Area}

Lake Taihu is located in the lower reaches of the Yangtze River $\left(120.22^{\circ} \mathrm{E}-120.29^{\circ} \mathrm{E}, 31.48^{\circ}\right.$ $\mathrm{N}-31.55^{\circ} \mathrm{N}$ ). It has a water surface area of $2338.1 \mathrm{~km}^{2}$, an average water depth of $1.89 \mathrm{~m}$, and a storage volume of $44.28 \times 10^{8} \mathrm{~m}^{3}$ [31]. Lake Taihu is a typical flat shallow lake with comprehensive functions of flood control, water supply, aquaculture, tourism, and ecology. However, since the 1980s, the rapid economic development of the basin has led to the increasing nutrient load to Lake Taihu, and the local water bodies and sediments have become seriously polluted [31]. The algal bloom in 2007 brought a serious water crisis to Wuxi City [32]. 
In the current study, Lake Taihu was divided into five regions, namely, north, northwest, southwest, northeast, and south lake regions (Figure 1). Zhushan Bay, Meiliang Bay, and Gonghu Bay with relatively serious pollution comprised the north lake area. Manshan Lake and Xukou Bay were distributed in the northeast lake area. East Tai Lake was distributed in the southern lake area.

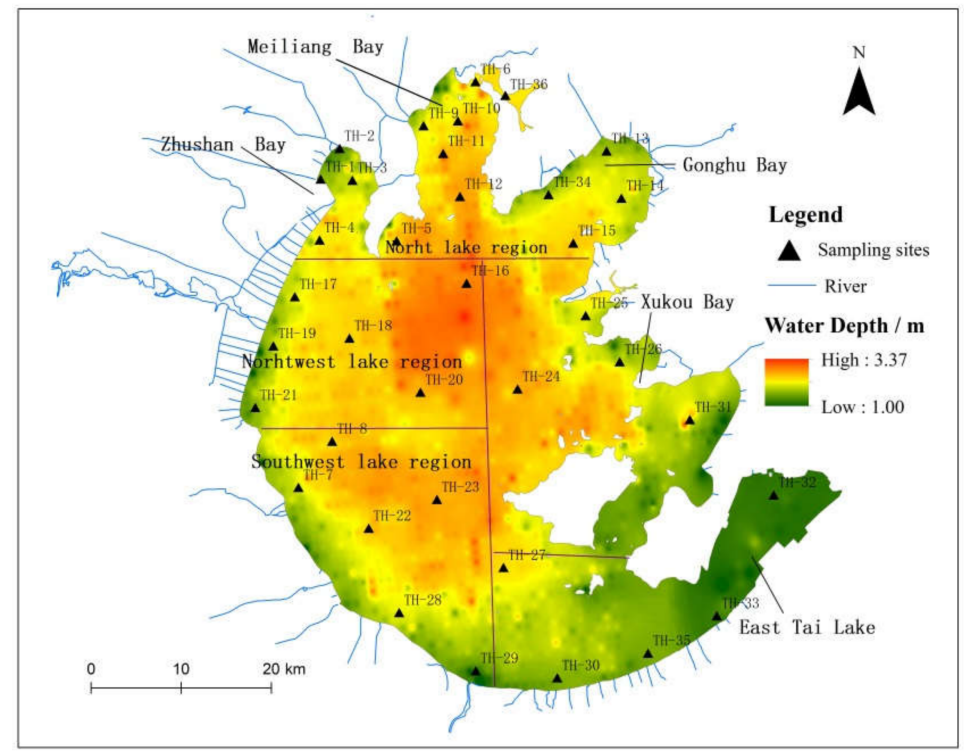

Figure 1. Location map of sampling stations in Lake Taihu.

\subsection{Sample Collection and Treatment}

Since 2009, Jiangsu Province Hydrology and Water Resources Investigation Bureau has conducted the daily inspection of the areas prone to algal blooms in Taihu Lake from April to October every year. According to statistics, the algal blooms concentrated in the period from May to September, and only one occurred in early October. The earliest occurrence of algal blooms occurred on 15 May in 2017. Hence, the overlying water samples from 36 sampling sites (Figure 1) in Lake Taihu were collected on 15-18 May at the early stage of algal blooms in Taihu in 2017. The accurate positions of all sampling sites were recorded by a global positioning system. At a depth of $0.5 \mathrm{~m}$ for each sampling site, approximately $2 \mathrm{~L}$ of water was collected into a clean plastic tub using a plexiglass hydrophore. Water temperature (T), pH, dissolved oxygen (DO), and water transparency were tested in the field. The water samples stored in a low temperature incubator were immediately sent to the field station and filtered through precombusted $\left(450^{\circ} \mathrm{C}\right.$ for $4 \mathrm{~h}$ ) Whatman $\mathrm{GF} / \mathrm{F}$ (porosity $=0.7 \mu \mathrm{m}$ ). The filtrate was stored in dark and cold conditions $\left(4^{\circ} \mathrm{C}\right)$ to minimize potential changes in DOM properties before the analyses. Dissolved organic carbon (DOC) was analyzed using a total organic carbon analyzer (TOC-V, Shimadzu, Japan) to represent the content of DOM. The contents of chl. $a$ were analyzed by the spectrophotometric method [33]. The permanganate index (COD $\left.\mathrm{Cn}_{\mathrm{n}}\right)$ was analyzed according to the national standard GB 11892-89 of China [34]. Dissolved total nitrogen (DTN) was analyzed by the alkaline potassium persulfate digestion UV spectrophotometric method [35] with the limit of detection (LOD) being $0.05 \mathrm{mg} / \mathrm{L}$. Ammonia nitrogen $\left(\mathrm{NH}_{4}{ }^{+}-\mathrm{N}\right)$ and nitrate nitrogen $\left(\mathrm{NO}_{3}{ }^{-}-\mathrm{N}\right)$ were analyzed by Nessler's reagent spectrophotometry [36] and the spectrophotometric method [37], and the LOD was 0.025 and $0.003 \mathrm{mg} / \mathrm{L}$, respectively. The concentration of dissolved organic nitrogen (DON) was calculated using the formula $\mathrm{DON}=\mathrm{DTN}-\mathrm{NO}_{3}{ }^{-} \mathrm{N}-\mathrm{NH}_{4}{ }^{+}-\mathrm{N}$. Dissolved total phosphorus (DTP) and dissolved inorganic phosphorus (DIP) were analyzed with the ammonium molybdate spectrophotometric method [38] with the LOD of $0.01 \mathrm{mg} / \mathrm{L}$. Dissolved organic phosphorus (DOP) was calculated using the formula DOP $=$ DTP - DIP. 


\subsection{Measurement of $C D O M$}

The absorption spectra of CDOM were scanned at wavelengths ranging from 200 to $800 \mathrm{~nm}$ ( $1 \mathrm{~nm}$ intervals) using a DR5000 UV-Vis spectrometer (Hach, CO, USA) with a $1 \mathrm{~cm}$ quartz cuvette. Absorbance measurements were baseline-corrected using ultrapure water. The absorption coefficient $\left(a_{\lambda}:\left(\mathrm{m}^{-1}\right)\right)$ was calculated according to the equation [39]:

$$
\alpha_{\lambda}=2.303 A(\lambda) / l
$$

where $l$ is the path-length of the optical cell in meters, and $A(\lambda)$ is the absorbance at a certain wavelength.

\subsection{Measurement of EEM Data}

Fluorescence spectra were measured using a Hitachi F-7000 fluorescence spectrometer (Hitachi, Japan) with a $1 \mathrm{~cm}$ quartz cuvette. Aliquots of samples were diluted prior to fluorescence measurements until UV absorbance at $254 \mathrm{~nm}$ reached below $0.1 / \mathrm{cm}$ to limit the influence of the inner filtering effects. All F-EEMs of the diluted samples were measured at excitation wavelengths ranging from 200 to $450 \mathrm{~nm}$ ( $5 \mathrm{~nm}$ increments) and emission wavelengths ranging from 250 to $600 \mathrm{~nm}$ ( $5 \mathrm{~nm}$ increments). Excitation and emission slits were adjusted to $5 \mathrm{~nm}$, and scanning speed was set to $1200 \mathrm{~nm} / \mathrm{min}$.

\subsection{Data Preprocessing}

\subsubsection{PARAFAC Analysis}

PARAFAC is an iterative type three-dimensional array decomposition algorithm based on the alternating least squares principle. On the basis of trilinear decomposition theory, PARAFAC decomposes a three-dimensional array $X$ composed of EEM data into a three-load matrix and then unfolds the three-dimensional fluorescence spectrum of CDOM [40]. This algorithm can objectively identify the characteristics and concentrations of the fluorescence components in samples.

The data on the fluorescence spectrum scanning of the samples should be pretreated. To avoid arbitrary units and any fluctuations in instrumental conditions, ultrapure water fluorescence spectra were measured to eliminate water Raman scatter peaks and convert EEMs to Raman units (R.U.) by normalizing them to the area under the Raman peak at a $350 \mathrm{~nm}$ excitation wavelength [41]. The specific methods and steps are based on our previous paper [42]. The pretreated data were analyzed by PARAFAC modeling in MATLAB with the DOM Fluor toolbox [43]. The core consistency test and split-half validation were conducted to test the effectiveness of the PARAFAC modeling and to determine the optimal number of DOM components [43]. The fluorescence intensities of the individual components were used to represent their relative concentrations in the extracts.

The total fluorescence intensity $F_{t}$ and the proportion of the $n$th fluorescence component to the total components were determined using the following equation:

$$
\begin{aligned}
& F_{t}=\sum_{1}^{n} F_{n} \\
& P_{n}=F_{n} / F_{t}
\end{aligned}
$$

\subsubsection{Calculation of Fluorescence Index}

Fluorescence index (FI) was calculated as the fluorescence intensity ratio of the fluorescence emission spectrum at 450 and $500 \mathrm{~nm}$ with the excitation light wavelength of $370 \mathrm{~nm}$ [44].

Humification index (HIX) was calculated by dividing the peak area of the emission wavelengths $435-480 \mathrm{~nm}$ by the peak area of the emission wavelengths $300-345 \mathrm{~nm}$ at the excitation wavelength of $254 \mathrm{~nm}$ [44]. 
Index of the recent autochthonous contribution (BIX) was determined as the ratio of fluorescence intensity at $380 \mathrm{~nm}$, divided by that at $430 \mathrm{~nm}$, both excited at $310 \mathrm{~nm}$ [45].

\subsection{Statistical Analysis}

A location map of sampling points was drawn in ArcGIS 10.2. The spatial distribution of the concentrations of DOM and CDOM and the fluorescence intensity of CDOM were determined with ArcGIS 10.2. The correlation analysis was completed in SPSS 19.0. The regression analysis and PCA were completed in Origin 9.0. The statistical analyses of the mean value, standard deviation, and $t$-test were performed using Excel 2010 and SPSS 19.0. Differences in parameters were assessed with independent sample $t$-tests $(p<0.05)$.

\section{Results}

\subsection{Basic Physical-Chemical Parameters of Overlying Water}

During the sampling period, the average water temperature was $23.8^{\circ} \mathrm{C}$, DO was 3.9-15.3 mg/L, $\mathrm{pH}$ was 7.93-9.82 (Table 1), and the water was weakly alkaline. The water was eutrophic to hypereutrophic, with a chl. $a$ content of $6.8-648 \mathrm{mg} / \mathrm{m}^{3}$. The chl. $a$ presented an increasing trend from southeast to northwest. The high values of chl. $a$ were mainly concentrated in the northwest and northern lake areas, with the average concentrations being 327.35 and $111.98 \mathrm{mg} / \mathrm{m}^{3}$, respectively. The concentration of chl. $a$ in the southern lake area was the lowest, and the average value was $12.9 \mathrm{mg} / \mathrm{m}^{3}$. COD $\mathrm{Mn}$ ranged from 2.00 to $76.75 \mathrm{mg} / \mathrm{L}$, with the average value being $11.24 \pm 15.91 \mathrm{mg} / \mathrm{L}$.

Table 1. Basic physical-chemical indices of the overlying water of Taihu Lake. Units: $\mathrm{mg} / \mathrm{L}=$ dissolved oxygen (DO), permanganate index $\left(\mathrm{COD}_{\mathrm{Mn}}\right)$, dissolved total nitrogen (DTN), dissolved organic nitrogen $(\mathrm{DON})$, dissolved total phosphorus (DTP), and dissolved organic phosphorus (DOP) contents; ${ }^{\circ} \mathrm{C}=\mathrm{T}$; $\mathrm{mg} / \mathrm{m}^{3}=$ chl. $a$.

\begin{tabular}{ccccccccccc}
\hline Lake Region & Items & T & DO & pH & Chl. $a$ & COD $_{\mathbf{M n}}$ & DTN & DON & DTP & DOP \\
\hline \multirow{5}{*}{ North } & Mean & 24.4 & 10.8 & 9.02 & 105 & 9.87 & 1.91 & 0.72 & 0.07 & 0.06 \\
& Min & 23.1 & 3.9 & 7.93 & 10.3 & 2.00 & 0.56 & 0.01 & 0.02 & 0.01 \\
& Max & 25.3 & 15.3 & 9.82 & 332 & 29.21 & 4.03 & 1.71 & 0.13 & 0.13 \\
\cline { 2 - 10 } Northwest & Mean & 23.4 & 8.8 & 8.53 & 327 & 31.65 & 3.61 & 2.06 & 0.12 & 0.12 \\
& Min & 21.8 & 6.4 & 8.02 & 150 & 5.63 & 1.94 & 0.84 & 0.02 & 0.02 \\
& Max & 24.3 & 12.6 & 9.20 & 648 & 76.75 & 5.86 & 3.04 & 0.28 & 0.26 \\
\cline { 2 - 10 } Southwest & Mean & 23.5 & 9.2 & 8.70 & 28.4 & 4.35 & 1.43 & 0.38 & 0.03 & 0.03 \\
& Min & 22.6 & 8.0 & 8.14 & 12.5 & 2.08 & 0.99 & 0.09 & 0.02 & 0.02 \\
Northeast & Max & 24.1 & 10.4 & 9.06 & 60.9 & 7.71 & 1.81 & 0.92 & 0.04 & 0.04 \\
\cline { 2 - 10 } & Mean & 22.5 & 8.9 & 8.37 & 13.3 & 7.34 & 1.04 & 0.21 & 0.02 & 0.02 \\
& Min & 22.1 & 8.2 & 8.18 & 7.8 & 2.05 & 0.97 & 0.06 & 0.02 & 0.02 \\
South & Max & 23.0 & 9.6 & 8.49 & 23.6 & 12.92 & 1.17 & 0.42 & 0.02 & 0.02 \\
\cline { 2 - 10 } & Mean & 23.5 & 8.3 & 8.24 & 12.9 & 2.26 & 1.59 & 0.25 & 0.03 & 0.03 \\
& Min & 22.8 & 8.1 & 8.07 & 6.8 & 2.00 & 1.35 & 0.06 & 0.02 & 0.02 \\
Whole lake & Max & 24.1 & 8.5 & 8.60 & 18.7 & 2.83 & 1.99 & 0.45 & 0.04 & 0.04 \\
\cline { 2 - 10 } & Mean & 23.8 & 9.6 & 8.70 & 106 & 11.24 & 1.97 & 0.77 & 0.06 & 0.05 \\
& Min & 21.8 & 3.9 & 7.93 & 6.8 & 2.00 & 0.56 & 0.01 & 0.02 & 0.01 \\
\hline
\end{tabular}

The concentrations of DTP and DOP in water were in the ranges of $0.02-0.28$ and $0.01-0.27 \mathrm{mg} / \mathrm{L}$, respectively, and their spatial distribution trends were highly consistent, showing a decreasing trend from the southeast to the northwest lake region. The order of DTP and DOP concentrations in each lake region was as follows: northwest lake region $>$ north lake region $>$ southwest lake region $>$ south 
lake region $>$ northeast lake region. The proportion of DOP in DTP ranged from $88.1 \%$ to $96.4 \%$, with the value slightly varying among the lake regions. The average value was $91.2 \%$, which indicated that DOP was the dominant component of DTP.

The concentrations of DTN and DON were $0.56-5.86$ and $0.01-3.04 \mathrm{mg} / \mathrm{L}$, respectively. The spatial distributions of DTN and DON were similar to those of DTP and DOP. The high values concentrated in the northwest and northern lake regions. The highest values of DTN and DON were observed in the northwest lake region, with the average concentrations being 3.61 and $2.06 \mathrm{mg} / \mathrm{L}$, respectively. The lowest values of DTN and DON were noted in the northeast lake region, and the average values were 1.04 and $0.21 \mathrm{mg} / \mathrm{L}$, respectively. DON accounted for $15.8-57.1 \%$ of DTN, and the mean percentage was $31.6 \%$. The concentration of DON varied among the lake regions and showed the following trend: northwest lake region $>$ north lake region $>$ southwest lake region $>$ south lake region $>$ northeast lake region; such a trend was similar to that of chl. $a$. DON was the dominant component of DTN in the northwest lake region with the highest eutrophication degree. By contrast, dissolved inorganic nitrogen (DIN) was the main component of DTN in the other lake regions.

\subsection{Spatial Distributions of DOM and CDOM in Overlying Water}

The concentration of DOM in the whole lake ranged from 2.86 to $11.83 \mathrm{mg} / \mathrm{L}$ (average, $4.38 \pm$ $1.87 \mathrm{mg} / \mathrm{L}$ ) and showed an increasing trend from southeast to northwest (Figure 2a). The average DOM concentration of each lake region revealed the order of northwestern lake region $>$ northern lake region $>$ southwestern lake region $>$ northeastern lake region $>$ southern lake region.
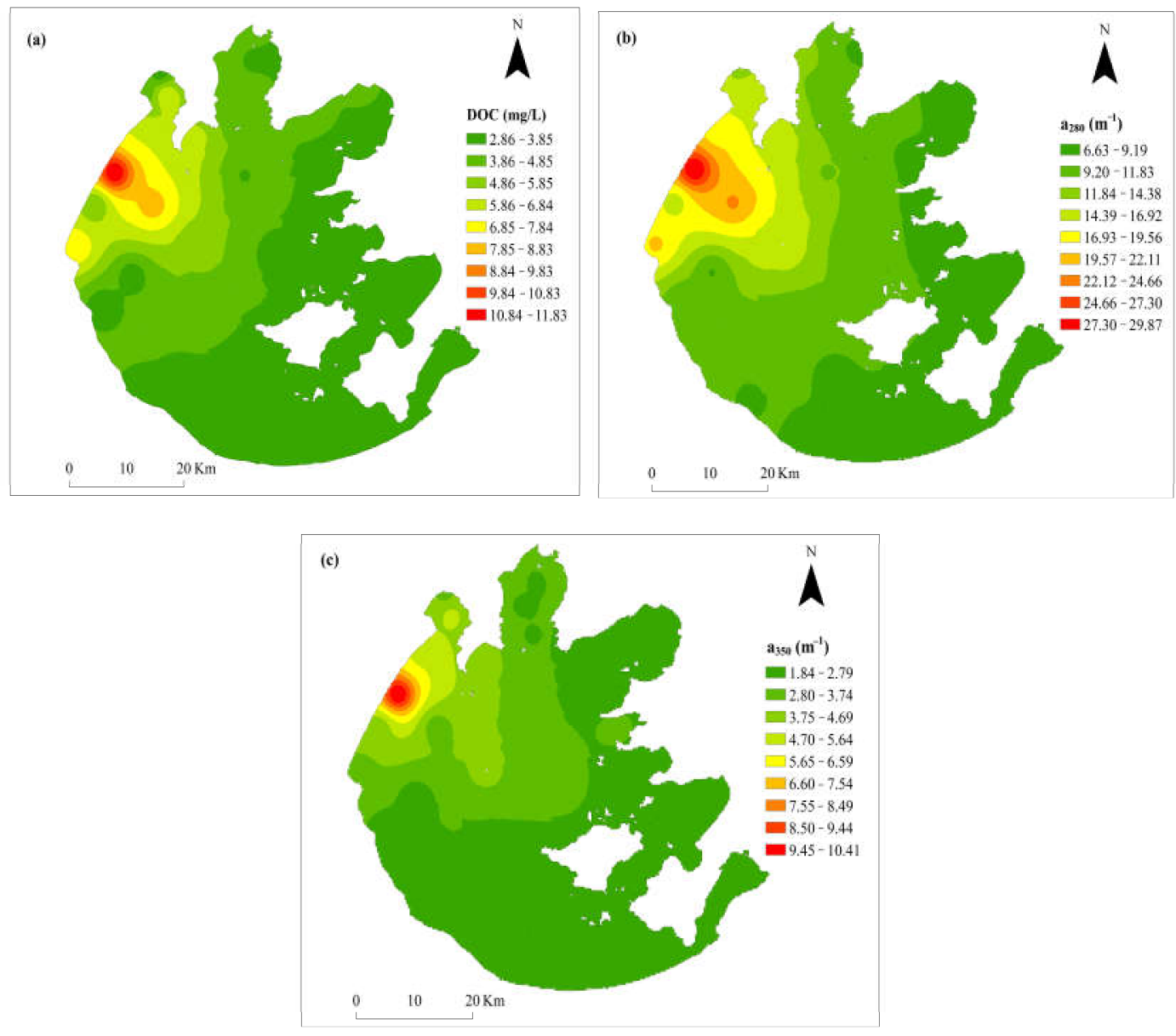

Figure 2. Spatial distributions of dissolved organic matter (DOM) and colored dissolved organic matter (CDOM; $\left.a_{280}, a_{350}\right)$ in the overlying water of Lake Taihu. (a) DOC; (b) $a_{280} ;$ (c) $a_{350}$. 
The abundance of CDOM is usually represented by the absorption coefficient at a representative wavelength (e.g., 350, 280, or $254 \mathrm{~nm}$ ) [46-48]. The $a_{280}$ values of the whole lake ranged from 6.63 to $29.87 \mathrm{~m}^{-1}$, with a mean value of $12.03 \pm 4.87 \mathrm{~m}^{-1}$, and showed an increasing trend from southeast to northwest (Figure $2 \mathrm{~b}$ ). The $a_{280}$ values in the northwestern and northern lake regions, with mean values of $19.44 \mathrm{~m}^{-1}$ and $12.04 \mathrm{~m}^{-1}$, respectively, were relatively higher than the average $a_{280}$ of the whole lake. The $a_{350}$ was $1.84-10.41 \mathrm{~m}^{-1}$ and the mean value was $3.06 \pm 1.57 \mathrm{~m}^{-1}$. The spatial distribution of $a_{350}$ was consistent with that of $a_{280}$ (Figure 2c). The high values of $a_{350}$ were also concentrated in northwestern and northern lake regions, with mean values of 4.66 and $3.21 \mathrm{~m}^{-1}$, respectively; these values were higher than the average $a_{350}$ of the whole lake. The CDOM concentration $\left(a_{350}\right)$ of Lake Taihu was higher than that of Lake Tianmu $\left(2.32 \pm 0.59 \mathrm{~m}^{-1}\right)$ [49], Lake Honghu (3.53-4.37 $\left.\mathrm{m}^{-1}\right)$, Lake Donghu (2.93-4.15 $\left.\mathrm{m}^{-1}\right)$, and Lake Liangzi (1.39-2.52 $\left.\mathrm{m}^{-1}\right)$ [50], thus indicating that the CDOM concentration of Lake Taihu was relatively high and varied among different lake regions.

\subsection{Three-Dimensional Fluorescence Spectrum Characteristics of CDOM in Overlying Water}

The PARAFAC method was used to analyze the 3D fluorescence spectral matrix data of CDOM in the overlying water of Lake Taihu, and a total of three components were identified (Figure 3). The three components identified from the fluorescence spectra corresponded to protein-like $\mathrm{C} 1, \mathrm{C} 2$, and humic-like C3 components. Component C1 had two obvious excitation wavelengths at 224 and $276 \mathrm{~nm}$, and its maximum emission wavelength was approximately $316 \mathrm{~nm}$, which reflects the fluorescence peak of tyrosine-like components formed by biodegradation [51]. The related studies $[45,51]$ reveal that tryptophan has poor stability, a high turnover rate, and easy mineralization and decomposition characteristics, and tryptophan is important organic carbon and $\mathrm{N}$ sources for plants and microorganisms due to its high activity. Component $\mathrm{C} 2$ had two obvious excitation wavelengths at 232 and $296 \mathrm{~nm}$, and its maximum emission wavelength was approximately $348 \mathrm{~nm}$, which reflects the fluorescence peak formed by tryptophan-like components [51]. Component C3 had two distinct excitation wavelengths at 260 and $340 \mathrm{~nm}$, and its maximum emission wavelength was near $450 \mathrm{~nm}$, which reflects the fluorescence peak formed by humic- and fulvic-like acids [51].

The fluorescence intensities of $\mathrm{C} 1, \mathrm{C} 2$, and $\mathrm{C} 3$ and the total fluorescence intensity $\left(F_{t}\right)$ of FDOM in the overlying water of Lake Taihu were shown as Table 2. $F_{t}$ ranged from 1.11 R.U. to 7.50 R.U. with a mean value of 3.38 R.U. $F_{t}$ presented an increasing trend from southeast to northwest in the order of the northwestern lake region $>$ northern lake region $>$ southwestern lake region $>$ southern lake region $>$ northeastern lake region. The $F_{t}$ at site TH-17 in the northwestern lake region was the highest among the values obtained; the algal bloom at this point was also notably the most serious. The mean fluorescence intensities of components $\mathrm{C} 1\left(F_{\mathrm{C} 1}\right), \mathrm{C} 2\left(F_{\mathrm{C} 2}\right)$, and $\mathrm{C} 3\left(F_{\mathrm{C} 3}\right)$ respectively were $1.65,1.30$, and 0.42 R.U., accounting for $49.59 \%, 37.96 \%$, and $12.46 \%$ of $F_{t}$. The fluorescence intensity of protein-like components $\left(F_{\mathrm{C} 1+\mathrm{C} 2}\right)$ accounted for $87.55 \%$ of $F_{t}$. 

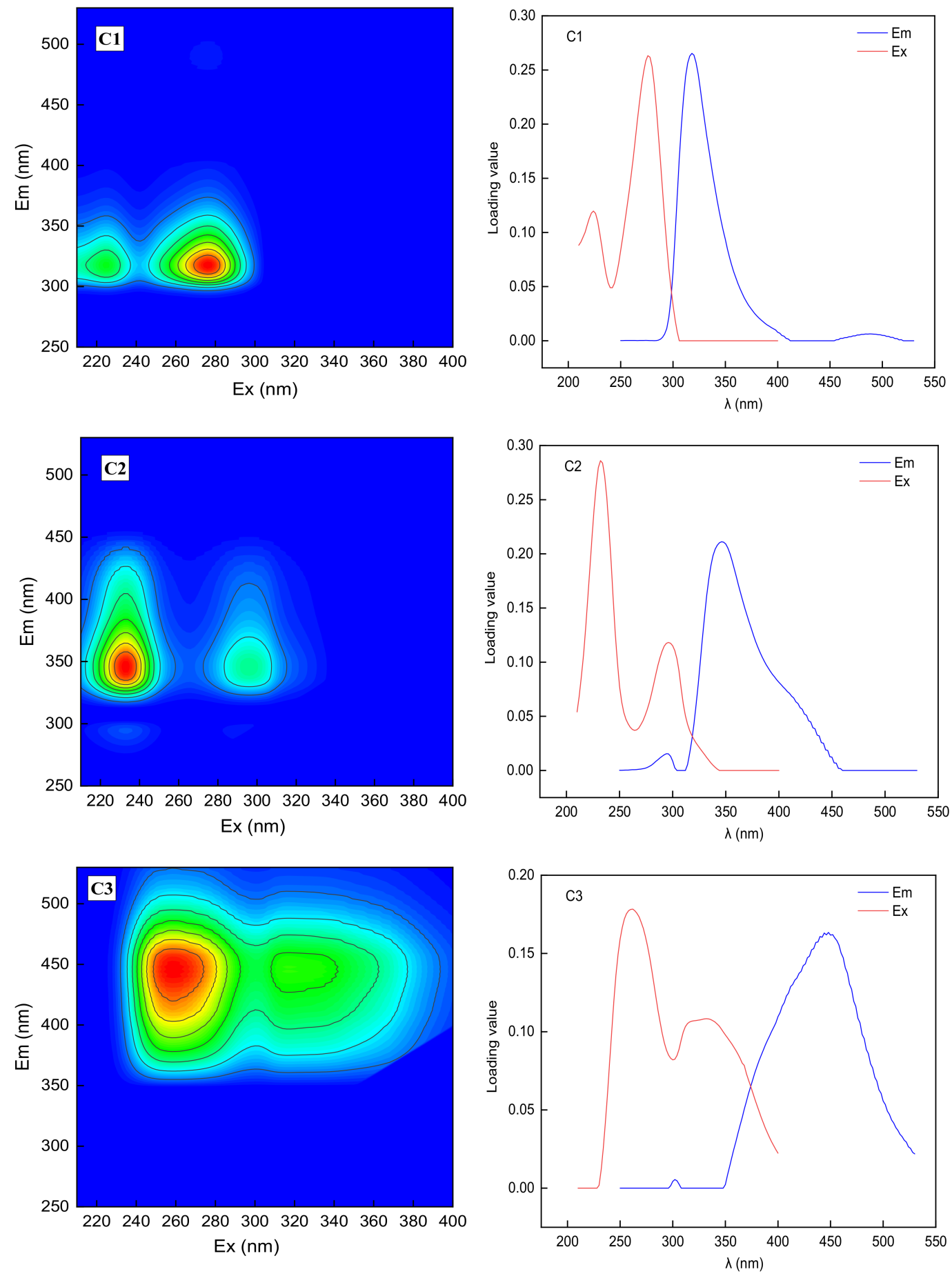

Figure 3. Fluorescence spectra of components of CDOM identified by the parallel factor analysis (PARAFAC) model in the overlying water of Lake Taihu. 
Table 2. Fluorescence intensities of components $\mathrm{C} 1\left(F_{\mathrm{C} 1}\right), \mathrm{C} 2\left(F_{\mathrm{C} 2}\right), \mathrm{C} 3\left(F_{\mathrm{C} 3}\right)$, and the total fluorescence intensity $\left(F_{t}\right)$ of fluorescent DOM (FDOM) in the overlying water of Taihu Lake.

\begin{tabular}{cccccc}
\hline Lake Region & Items (R.U.) & $\boldsymbol{F}_{\mathbf{C} \mathbf{1}}$ & $\boldsymbol{F}_{\mathbf{C} 2}$ & $\boldsymbol{F}_{\mathbf{C} \mathbf{3}}$ & $\boldsymbol{F}_{\boldsymbol{t}}$ \\
\hline \multirow{3}{*}{ North } & Mean & 1.69 & 1.37 & 0.44 & 3.50 \\
& Min & 0.34 & 0.47 & 0.24 & 1.11 \\
& Max & 2.34 & 2.09 & 0.80 & 5.11 \\
\cline { 2 - 5 } Northwest & Mean & 2.60 & 2.19 & 0.77 & 5.56 \\
& Min & 1.88 & 1.54 & 0.42 & 3.84 \\
& Max & 3.41 & 3.02 & 1.07 & 7.50 \\
\cline { 2 - 6 } Southwest & Mean & 1.53 & 1.15 & 0.28 & 2.96 \\
& Min & 1.33 & 0.98 & 0.13 & 2.58 \\
& Max & 1.85 & 1.42 & 0.35 & 3.56 \\
\cline { 2 - 6 } Northeast & Mean & 0.95 & 0.63 & 0.25 & 1.84 \\
& Min & 0.88 & 0.57 & 0.23 & 1.68 \\
& Max & 1.08 & 0.73 & 0.29 & 2.11 \\
\cline { 2 - 6 } South & Mean & 1.11 & 0.76 & 0.26 & 2.13 \\
& Min & 0.94 & 0.64 & 0.25 & 1.84 \\
& Max & 1.32 & 0.91 & 0.29 & 2.48 \\
\cline { 2 - 6 } Whole lake & Mean & 1.65 & 1.30 & 0.42 & 3.38 \\
& Min & 0.34 & 0.47 & 0.13 & 1.11 \\
& Max & 3.41 & 3.02 & 1.07 & 7.50 \\
& SD & 0.64 & 0.62 & 0.23 & 1.45 \\
\hline
\end{tabular}

\section{Discussion}

\subsection{Reasons for the Spatial Distribution Characteristics of DOM in Overlying Water of Lake Taihu}

This survey results showed that the high DOM values were concentrated in the northwestern and northern lake regions with average concentrations of 6.97 and $4.41 \mathrm{mg} / \mathrm{L}$, respectively. The mean DOM concentrations in the two regions of Lake Taihu were higher than the average DOM of the whole lake. Such a finding may be explained by two reasons. First, the waters of Zhushan Bay and western region of Lake Taihu are greatly affected by human activities [52,53], and external sources can discharge DOM into the water. Second, the prevailing southeasterly wind in summer promotes the accumulation of cyanobacteria in downwind areas [54]. During the sampling period, cyanobacteria covered and deposited in the northwestern lake region and some water areas of Zhushan Bay in the northern lake region. At sample point TH-17, in particular, the thickness of cyanobacteria reached approximately $10 \mathrm{~cm}$. The DOM generated by the release and metabolism of algal activity is also an important reason behind the high relative DOM content in these water areas.

\subsection{Source Apportionment of DOM in Overlying Water of Lake Taihu}

The characteristics of the fluorescence components of DOM can reflect the source of DOM. In general, the terrestrial source is formed by the degradation of residues of higher plants and animals in the soil by bacteria and fungi. During migration of DOM from terrestrial sources, protein-like peaks are easily affected by photodegradation and microbial degradation; in most cases, humic-like peaks are dominant $[40,43,51]$. DOM from autochthonous sources refers to the production of plankton, aquatic bacteria, and algae, as well as other biological activities, in water and is mostly characterized by the absolute dominance of protein-like peaks [40,43,51]. DOM in Lake Taihu was dominated by protein-like components, which accounted for $85 \%$ of $\mathrm{F}_{\mathrm{t}}$, representing that the DOM might derive from autochthonous sources. This result was similar to the results of Miao et al. [55], who found that the DOM in the waters of Lake Taihu is mainly composed of tryptophan- and tyrosine-like protein substances during algal blooms. 
FI and BIX are good metrics for differentiating DOM from terrestrial and autochthonous sources. Generally, FI of DOM of approximately 1.40 and 1.90 indicates that the fluorescence emitting groups of DOM are mainly from terrestrial sources and autochthonous sources, respectively [44]. BIX can reflect the proportion of newly generated DOM in the overall DOM [56]. The higher the BIX, the higher the proportion of newly generated autochthonous DOM. BIX of 0.6-0.7 means the DOM has weak autochthonous characteristics, while BIX of 0.7-0.8 means the DOM has moderate autochthonous characteristics [56]. A BIX of 0.8-1.0 means the DOM has strong autochthonous characteristics, and a BIX above 1.0 means DOM is produced by microbial and bacterial activities [56]. The FI values in the overlying water of Lake Taihu were 1.63-2.19, with a mean value of 1.77. The BIX values of DOM in the overlying water of Lake Taihu were in the range of $0.74-1.11$ with a mean value of 0.92 . BIX values in over $70 \%$ of the sampling sites exceeded 0.9 . Values of FI and BIX indicated that DOM in the overlying water of Lake Taihu had strong autochthonous characteristics and might derive from autochthonous sources.

This study was conducted at the early stage of algal bloom in Lake Taihu. The mean content of chl. a reached $109.23 \mathrm{mg} / \mathrm{m}^{3}$ and exceeded $500 \mathrm{mg} / \mathrm{m}^{3}$ in the northwestern lake region, where a large amount of algae accumulated; indeed, this region is a typical area of severe eutrophication. To determine whether the DOM in the water of Lake Taihu at the early stage of algal bloom was related to algae, a correlation analysis and regression analysis were conducted between the relevant indicators of DOM and chl. $a$ concentration (Figure 4).
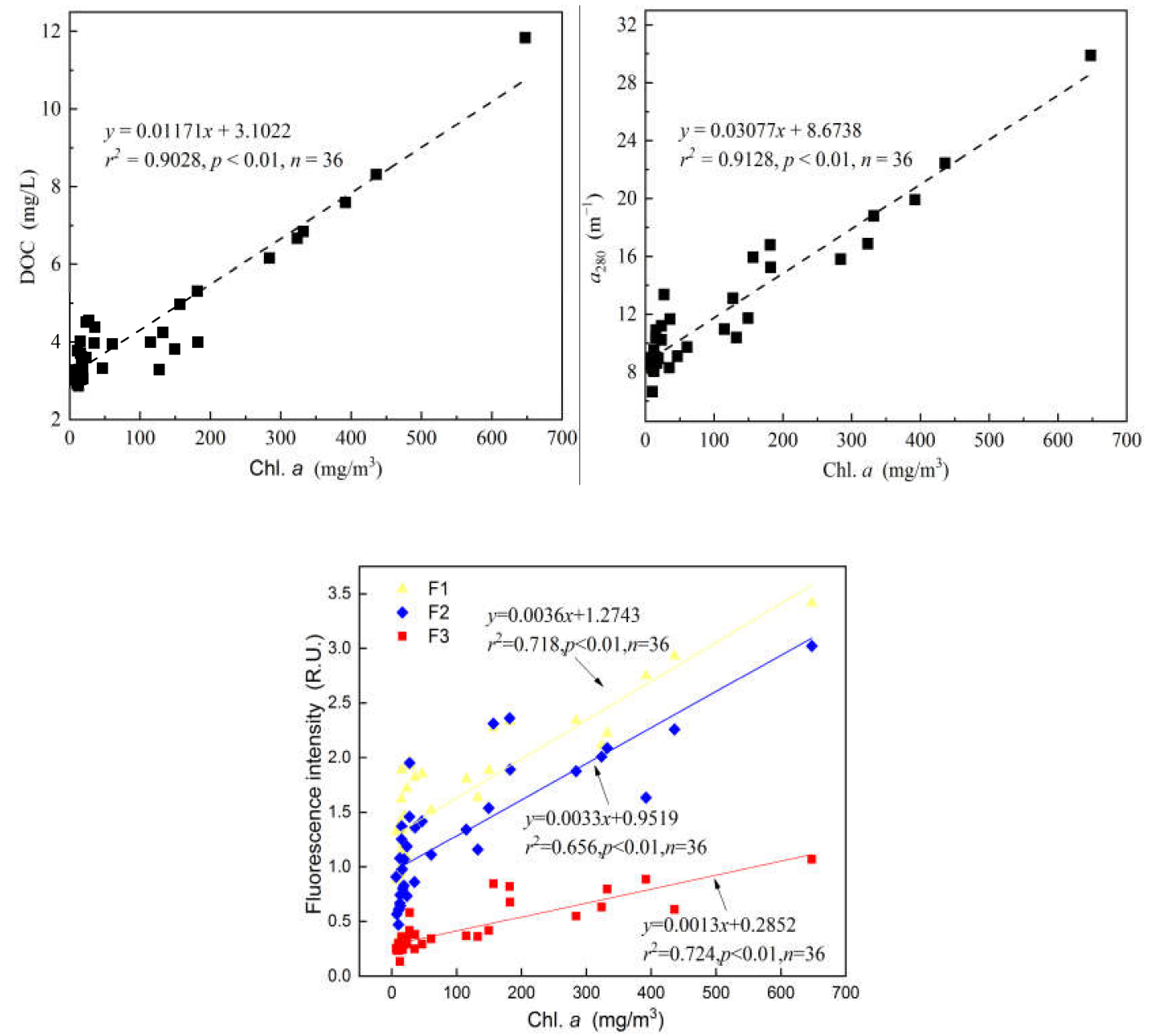

Figure 4. Correlations between dissolved organic carbon (DOC), $a_{280}$, and fluorescence intensities of the components of FDOM and chl. $a$ in the overlying water of Lake Taihu. 
DOC and $a_{280}$ were all significantly and positively correlated with chl. $a(p<0.01)$, with the determination coefficients $r^{2}$ of the regression equations were above 0.9 (Figure 4). This finding indicated that DOM and CDOM might derive from the same sources and over $90 \%$ of the DOM and CDOM fluctuations could be explained by the change in chl. $a$ in the early stages of algal bloom. Significant positive correlation $(p<0.01)$ between chl. $a$ and fluorescence intensity of each component was also found, indicating that FDOM might also be closely related to algal activity. A large amount of intracellular DOM can be generated by the activity, decay, and lysis of algae during algal blooms $[57,58]$. DOM can also be generated by the byproducts of bacterial respiration and death during in situ bacterial degradation, resulting in extensive DOM aggregation in water [27]. In this study, DOC was significantly correlated with chl. $a(p<0.01)$, which is different from the results of Ye et al. [1]; variations observed between the two studies may be mainly due to differences in sampling time and location. The sampling time of the study of Ye et al. [1] ran from March to August, and the group set up only three sampling points at Meiliang Bay, Gonghu Bay, and the middle of Lake Taihu. By comparison, in the present study, we set up 36 sampling sites over the whole lake at the early stage of algal bloom. Hence, the effect of algae on water DOM is relatively more pronounced in this work, whose results could better reflect the overall situation of the lake during initial bloom formation in mid-May.

\subsection{Characteristics of Algal-Derived DOM in the Overlying Water of Lake Taihu}

HIX is an ideal index to characterize the humification degree of DOM. HIX values below 4 indicates that DOM is mainly produced by biological activities and its humification degree is weak [44]. The HIX values of DOM in the overlying water of Lake Taihu ranged from 0.26 to 1.94, with a mean value of 0.66 , which is far less than 4 . Additionally, the HIX value was also significantly lower than that of Lake Tiancai (4.25) [59], Lake Baihua (2.88-5.63) [60], Changshou Lake (3.10-6.47) [61], and Lake Michigan (2.33) [62], indicating a weak humification degree for DOM. The difference of HIX between Lake Taihu and the other lakes was mainly caused by the source and component of DOM. DOM in the water of Lake Taihu mainly derived from autochthonous sources and was closely related to algal biomass. The DOM was also dominated by protein-like components. DOM in the water of Lake Tiancai and Lake Michigan mainly derived from terrestrial sources, and dominated by humic-like components. The main components of DOM in the water of Lake Baihua and Changshou Lake were humic-like and fulvic-like components. Hence, the humification degree of DOM in Lake Taihu was lower than that of the compared four lakes.

In this study, extremely significant and positive linear correlations were observed among $a_{280}$, fluorescence intensities of the FDOM components, and DOC $(p<0.01)$, and the regression relationships were shown in Figure 5. This may be explained by the fact that CDOM and FDOM are from the same source and influenced by chl. $a$. This supposition is consistent with the results of research on the Xinanjiang River [63] and Meiliang Bay in summer [21]. The intensities of the three fluorescence components were also significantly and positively correlated with $a_{280}(p<0.01)$, indicating that algal-derived CDOM may contain strong aromatic structures or conjugate chromophores.

DOM is closely related to the circulation of $\mathrm{N}$ and $\mathrm{P}$, and directly affects the conversion of matter and energy in the ecosystem [64]. DOM and nutrients participate together in various important physical, chemical, and biological processes in the ecosystem along with changes in their content and chemical structure [27]. The coupling relationship between these materials mainly refers to the complex interactions, such as degradation, use, and conversion, of/between OM and inorganic nutrients in these processes [27,65-68]. $\mathrm{N}$ and $\mathrm{P}$ are important chemical components of DOM [27]. During degradation of DOM, a large amount of oxygen is consumed, and $\mathrm{N}$ and $\mathrm{P}$ are simultaneously released, thus affecting the aquatic environment quality [66,69]. The DOC and $a_{280}$ were all significantly and positively correlated with DON and DOP in the overlying water of Lake Taihu $(p<0.01)$, and the regression coefficients ranged from 0.732 to 0.879 , which indicated that DOM might contain a portion of DON and DOP. PCA was also conducted to explore the relationships among algae, DOM, and N and $\mathrm{P}$ as shown in Figure 6. 

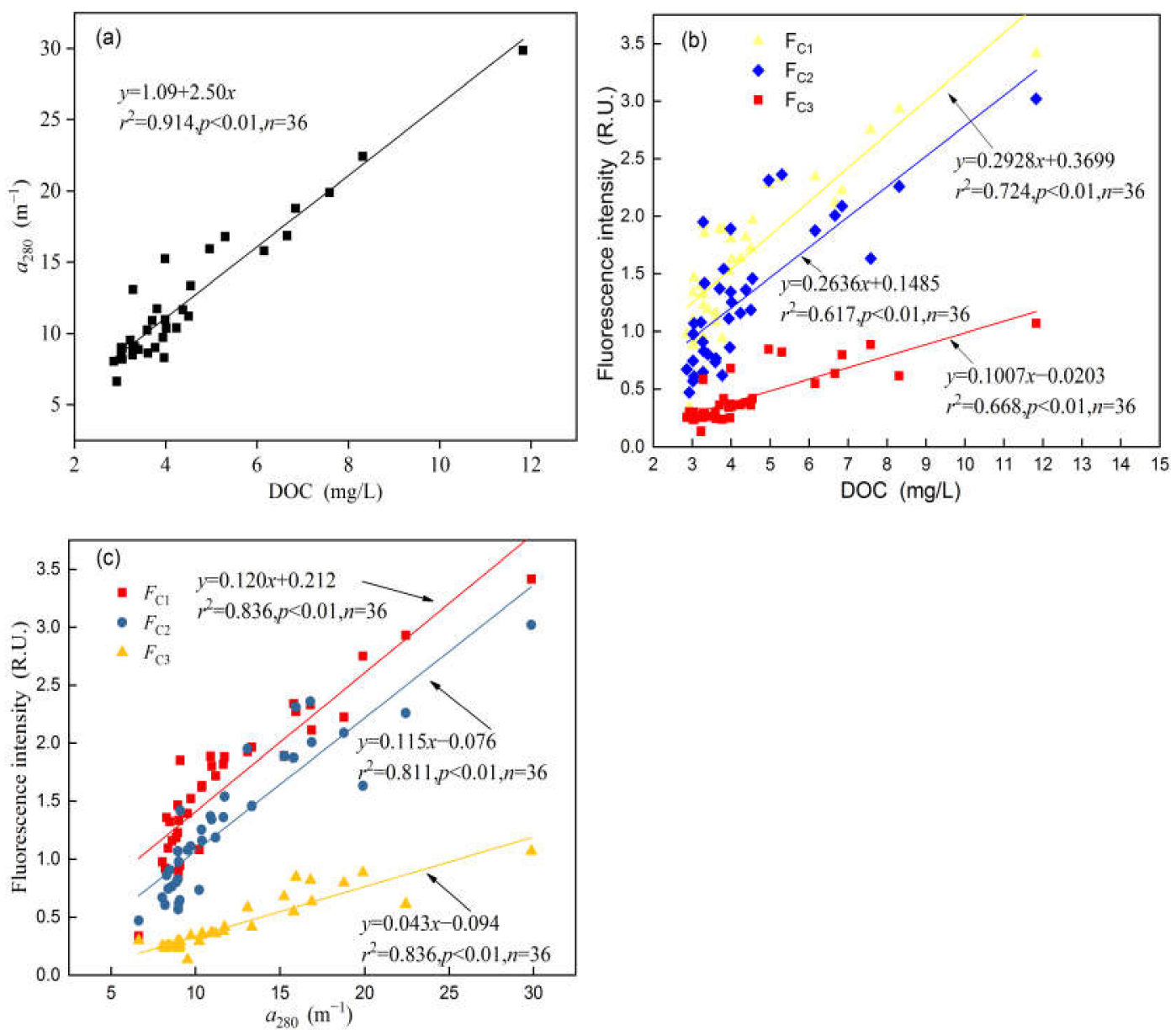

Figure 5. Correlation between $a_{280}$, DOC, and the fluorescence intensities of FDOM components in the overlying water of Lake Taihu. (a) Correlation between DOC and $a_{280}$; (b) Correlation between DOC and fluorescence intensities of FDOM components; (c) Correlation between $a_{280}$ and fluorescence intensities of FDOM components.

PCA results showed that the eigenvalues of the first two principal components were greater than 1 , and the cumulative variance interpretation rate was $96.81 \%$. The cumulative variance interpretation rate of PC1 reached $91.41 \%$, and all indices showed positive loads. Combined with the source analysis, PC1 could be interpreted as the factors of algae growth and degradation. The variance contribution rate of PC2 was only $5.42 \%$, and only $F_{t}, \mathrm{DON}$, and $a_{280}$ showed positive loads on PC2, which could be interpreted as protein-like factors caused by DOM. DOC, $a_{280}$, and $F_{t}$ were all significantly positively correlated with Chl. $a, \mathrm{DON}$, and DOP, indicating that DOM was closely related with $\mathrm{N}$ and $\mathrm{P}$ during the growth and death of alga. The points that contributed a lot to PC1 were TH-17, TH-18, TH-21, TH-3, TH-4, TH-5, TH-19, TH-20, and TH-1. The points were mainly concentrated in the northwest of Lake Taihu, where the content of chl. $a$ was extremely high, especially for TH-17, where the chl. $a$ concentration reached $647.74 \mathrm{mg} / \mathrm{m}^{3}$. Relevant research in Lake Taihu has shown that the DOM is affected by the post-cyanobacterial bloom in Lake Taihu, and the DOM release is likely caused by the cyanobacterial cell lysis induced by nitrate depletion [1]. DOC and DON are important components of DOM, the P in algae is also mostly organic P [70], thereby DOC, DON, and DOP can be released into water along with the cyanobacterial cell lysis during the blooms. The phytoplankton degradation experiment in Lake Taihu by Zhang et al. [45] showed that in the process of decomposition and death of algae, CDOM was rapidly released and then partially decomposed under the action of bacteria and other microorganisms. Some portion of the phytoplankton derived CDOM such as protein-like and 
fulvic acid-like substances are labile and rapidly degraded, and should make great contributions to the continuous occurrence of algal blooms [45].

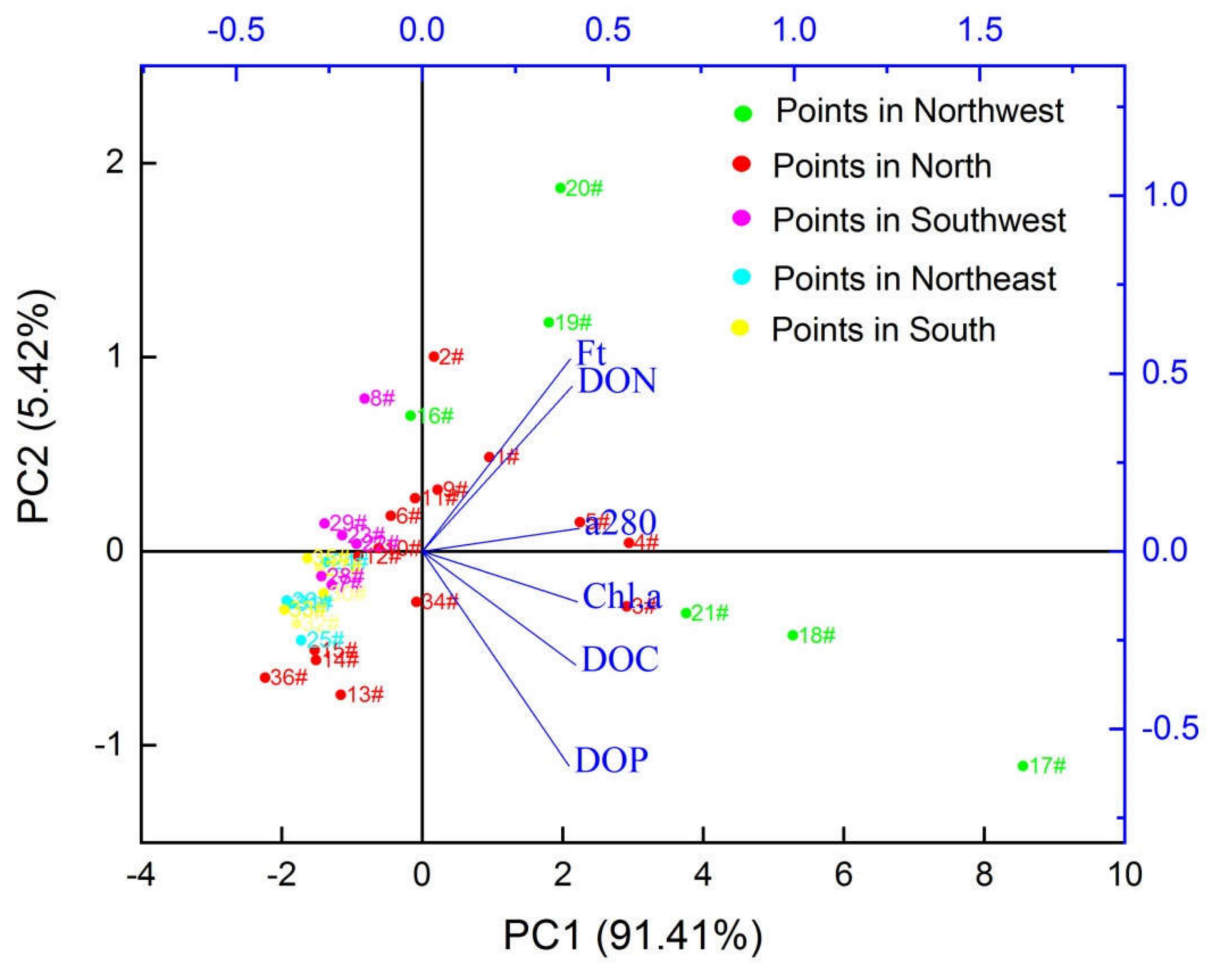

Figure 6. Plots of samples and variables from a principle components analysis of DOC, $a_{280}, F_{t}$, chl. $a$, DON, and DOP in the overlying water of Lake Taihu.

\section{Conclusions}

In the early stages of algal bloom in Lake Taihu, the spatial distribution characteristics of DOM and CDOM in the overlying water were similar and showed an increasing trend from southeast to northwest; high DOM and CDOM values were concentrated in the northwestern and northern lake regions with serious algal bloom. Three components (two protein-like and one humic-like), namely, tyrosine-like $\mathrm{C} 1$, tryptophan-like $\mathrm{C} 2$, and humic-like $\mathrm{C} 3$, were identified by the PARAFAC method, with the mean fluorescence intensity of $1.65,1.30$, and 0.42 R.U. Protein-like components $(\mathrm{C} 1+\mathrm{C} 2)$ were dominant components of DOM, accounting for $87.55 \% \pm 3.39 \%$ of the total fluorescence intensity (3.38 R.U.). At an early stage of algal bloom formation, DOM in the overlying water mainly came from algal activities and metabolites. The algal-derived DOM had a low humification degree and some labile and rapidly degraded components and could be important sources of nutrients for microbial decomposition and algal bloom formation.

Author Contributions: S.W. and W.W. wrote the paper and analyzed the data; S.W. and X.J. conceived and designed the experiments; W.W., J.C., B.Z. and L.Z. performed the experiments. All authors have read and agreed to the published version of the manuscript.

Funding: This research was funded by the Major Science and Technology Program for Water Pollution Control and Treatment of China, grant number 2017ZX07206.

Acknowledgments: The authors thank the participants of this study for their time and useful insights. This work was supported by the Major Science and Technology Program for Water Pollution Control and Treatment of China (Program No. 2017ZX07206).

Conflicts of Interest: The authors declare no conflict of interest. 


\section{References}

1. Ye, L.; Shi, X.; Wu, X.; Zhang, M.; Yü, Y.; Li, D.; Kong, F. Dynamics of dissolved organic carbon after a cyanobacterial bloom in hypereutrophic Lake Taihu (China). Limnologica 2011, 41, 382-388. [CrossRef]

2. Jiang, T.; Bravo, A.G.; Skyllberg, U.; Björn, E.; Wang, D.; Yan, H.; Green, N.W. Influence of dissolved organic matter $(\mathrm{DOM})$ characteristics on dissolved mercury $(\mathrm{Hg})$ species composition in sediment porewater of lakes from southwest China. Water Res. 2018, 146, 146-158. [CrossRef] [PubMed]

3. Wang, S.R.; Jin, X.C.; Zhao, H.C.; Zhou, X.N. Effect of DOM on phosphate sorption in lake sediments. Acta Pedol. Sin. 2005, 42, 805-811. [CrossRef]

4. Wei, Z.-M.; Zhang, X.; Wei, Y.-Q.; Wen, X.; Shi, J.; Wu, J.; Zhao, Y.; Xi, B. Fractions and biodegradability of dissolved organic matter derived from different composts. Bioresour. Technol. 2014, 161, 179-185. [CrossRef]

5. Zhang, Y.; Yang, R.; Wang, S.; Si, X.; Duan, X.; Zhou, J. Influence of humic substances on the toxic effects of cadmium and SDBS to the green alga Scenedesmus obliquus. Environ. Toxicol. Pharmacol. 2019, 68, 94-100. [CrossRef]

6. Yuan, D.; Wang, H.; An, Y.; Guo, X.; He, L. Insight into the binding properties of carbamazepine onto dissolved organic matter using spectroscopic techniques during grassy swale treatment. Ecotoxicol. Environ. Saf. 2019, 173, 444-451. [CrossRef]

7. Wu, J.; Zhang, H.; He, P.; Shao, L.-M. Insight into the heavy metal binding potential of dissolved organic matter in MSW leachate using EEM quenching combined with PARAFAC analysis. Water Res. 2011, 45, 1711-1719. [CrossRef]

8. Zepp, R.; Callaghan, T.; Erickson, D. Effects of enhanced solar ultraviolet radiation on biogeochemical cycles. J. Photochem. Photobiol. B Biol. 1998, 46, 69-82. [CrossRef]

9. Moran, M.A.; Sheldon, W.M.; Zepp, R. Carbon loss and optical property changes during long-term photochemical and biological degradation of estuarine dissolved organic matter. Limnol. Oceanogr. 2000, 45, 1254-1264. [CrossRef]

10. Organelli, E.; Bricaud, A.; Antoine, D.; Matsuoka, A. Seasonal dynamics of light absorption by chromophoric dissolved organic matter (CDOM) in the NW Mediterranean Sea (BOUSSOLE site). Deep Sea Res. Part I Oceanogr. Res. Pap. 2014, 91, 72-85. [CrossRef]

11. Kheireddine, M.; Ouhssain, M.; Calleja, M.L.; Morán, X.A.G.; Sarma, Y.; Tiwari, S.P.; Jones, B.H. Characterization of light absorption by chromophoric dissolved organic matter (CDOM) in the upper layer of the Red Sea. Deep Sea Res. Part I Oceanogr. Res. Pap. 2018, 133, 72-84. [CrossRef]

12. Stedmon, C.A.; Markager, S.; Tranvik, L.J.; Kronberg, L.; Slätis, T.; Martinsen, W. Photochemical production of ammonium and transformation of dissolved organic matter in the Baltic Sea. Mar. Chem. 2007, 104, 227-240. [CrossRef]

13. Sereda, J.M.; Hunter, K.; Vandergucht, D.; Hudson, J. Photochemical mineralization of dissolved organic nitrogen to ammonia in prairie lakes. Hydrobiologia 2012, 693, 71-80. [CrossRef]

14. Hu, B.; Wang, P.; Qian, J.; Wang, C.; Zhang, N.; Cui, X. Characteristics, sources, and photobleaching of chromophoric dissolved organic matter (CDOM) in large and shallow Hongze Lake, China. J. Great Lakes Res. 2017, 43, 1165-1172. [CrossRef]

15. Liu, W.-X.; He, W.; Wu, J.-Y.; Wu, W.-J.; Xu, F.-L. Effects of fluorescent dissolved organic matters (FDOMs) on perfluoroalkyl acids (PFAAs) in lake and river water. Sci. Total Environ. 2019, 666, 598-607. [CrossRef]

16. Wong, K.H.; Obata, H.; Kim, T.; Wakuta, Y.; Takeda, S. Distribution and speciation of copper and its relationship with FDOM in the East China Sea. Mar. Chem. 2019, 212, 96-107. [CrossRef]

17. Zahra, Z.; Maqbool, T.; Arshad, M.; Badshah, M.A.; Choi, H.-K.; Hur, J. Changes in fluorescent dissolved organic matter and their association with phytoavailable phosphorus in soil amended with $\mathrm{TiO} 2$ nanoparticles. Chemosphere 2019, 227, 17-25. [CrossRef]

18. Rochelle-Newall, E.; Fisher, T. Chromophoric dissolved organic matter and dissolved organic carbon in Chesapeake Bay. Mar. Chem. 2002, 77, 23-41. [CrossRef]

19. Spencer, R.G.M.; Aiken, G.R.; Butler, K.D.; Dornblaser, M.M.; Striegl, R.G.; Hernes, P.J. Utilizing chromophoric dissolved organic matter measurements to derive export and reactivity of dissolved organic carbon exported to the Arctic Ocean: A case study of the Yukon River, Alaska. Geophys. Res. Lett. 2009, 36. [CrossRef] 
20. Liu, M.L.; Zhang, Y.L.; Qin, B.Q. Characterization of absorption and three-dimensional excitation-emission matrix spectra of chromophoric dissolved organic matter at the river inflow and the open area in Lake Taihu. J. Lake Sci. 2009, 21, 234-241. [CrossRef]

21. Zhang, Y.L.; Qin, B.Q. Feature of CDOM and its possible source in Meiliang bay and Da Taihu lake in Taihu lake in summer and winter. Adv. Water Sci. 2007, 18, 415-423. [CrossRef]

22. Yao, X.; Zhang, Y.; Zhu, G.-W.; Qin, B.; Feng, L.; Cai, L.; Gao, G. Resolving the variability of CDOM fluorescence to differentiate the sources and fate of DOM in Lake Taihu and its tributaries. Chemosphere 2011, 82, 145-155. [CrossRef] [PubMed]

23. Lu, W.; Yao, X.; Shao, K.; Zhang, B.; Gao, G. Unraveling the sources and fluorescence compositions of dissolved and particulate organic matter (DOM and POM) in Lake Taihu, China. Environ. Sci. Pollut. Res. 2018, 26, 4027-4040. [CrossRef]

24. Sepp, M.; Kõiv, T.; Nõges, P.; Nõges, T. The role of catchment soils and land cover on dissolved organic matter (DOM) properties in temperate lakes. J. Hydrol. 2019, 570, 281-291. [CrossRef]

25. Yu, X.; Zhang, J.; Kong, F.; Li, Y.; Li, M.; Dong, Y.; Xi, M. Identification of source apportionment and its spatial variability of dissolved organic matter in Dagu River-Jiaozhou Bay estuary based on the isotope and fluorescence spectroscopy analysis. Ecol. Indic. 2019, 102, 528-537. [CrossRef]

26. Gu, L.; Huang, B.; Han, F.; Xu, Z.; Ren, D.; He, H.; Pan, X.; Dionysiou, D.D. Intermittent light and microbial action of mixed endogenous source DOM affects degradation of $17 \beta$-estradiol day after day in a relatively deep natural anaerobic aqueous environment. J. Hazard. Mater. 2019, 369, 40-49. [CrossRef]

27. Wu, F.C.; Wang, L.Y.; Li, W.; Zhang, R.Y.; Fu, P.Q.; Liao, H.Q.; Bai, Y.C.; Guo, J.Y.; Wang, J. Natural organic matter and its significance in terrestrial surface environment. J. Lake Sci. 2008, 20, 1-12.

28. Wang, Z.-G.; Liu, W.; Zhao, N.-J.; Li, H.-B.; Zhang, Y.-J.; Si-Ma, W.-C.; Liu, J. Composition analysis of colored dissolved organic matter in Taihu Lake based on three dimension excitation-emission fluorescence matrix and PARAFAC model, and the potential application in water quality monitoring. J. Environ. Sci. 2007, 19, 787-791. [CrossRef]

29. Zhou, Y.; Zhang, Y.; Shi, K.; Niu, C.; Liu, X.; Duan, H. Lake Taihu, a large, shallow and eutrophic aquatic ecosystem in China serves as a sink for chromophoric dissolved organic matter. J. Great Lakes Res. 2015, 41, 597-606. [CrossRef]

30. Zhang, F.; Harir, M.; Moritz, F.; Zhang, J.; Witting, M.; Wu, Y.; Schmitt-Kopplin, P.; Fekete, A.; Gáspár, A.; Hertkorn, N. Molecular and structural characterization of dissolved organic matter during and post cyanobacterial bloom in Taihu by combination of NMR spectroscopy and FTICR mass spectrometry. Water Res. 2014, 57, 280-294. [CrossRef]

31. Qin, B.; Xu, P.; Wu, Q.; Luo, L.; Zhang, Y. Environmental issues of Lake Taihu, China. Hydrobiologia 2007, 581, 3-14. [CrossRef]

32. Guo, L. Doing Battle With the Green Monster of Taihu Lake. Science 2007, 317, 1166. [CrossRef] [PubMed]

33. MEP of PRC (Ministry of Environmental Protection of the People's Republic of China). Water Quality-Determination of Chlorophyll-A Spectrophotometric Method; China Environmental Science Press: Beijing, China, 2017.

34. MEP of PRC (Ministry of Environmental Protection of the People's Republic of China). Water Quality_Determination of Permanganate Index; China Environmental Science Press: Beijing, China, 1989.

35. MEP of PRC (Ministry of Environmental Protection of the People's Republic of China). Water Quality-Determination of Total Nitrogen-Alkaline Potassium Persulfate Digestion UV Spectrophotometric Method (HJ 636-2012); China Environmental Science Press: Beijing, China, 2012.

36. MEP of PRC (Ministry of Environmental Protection of the People's Republic of China). Water Quality-Determination of Ammonia Nitrogen-Nessler's Reagent Spectrophotometry (HJ 535-2009); China Environmental Science Press: Beijing, China, 2009.

37. MEP of PRC (Ministry of Environmental Protection of the People's Republic of China). Water Quality-Determination of Nitrate-Nitrogen-Ultraviolet Spectrophotometry (HJ/T 346-2007); China Environmental Science Press: Beijing, China, 2009.

38. MEP of PRC (Ministry of Environmental Protection of the People's Republic of China). Water Quality-Determination of Total Phosphorus-Ammonium Molybdate Spectrophotometric Method (GB 11893-89); China Environmental Science Press: Beijing, China, 1989. 
39. Hu, C.; Muller-Karger, F.E.; Zepp, R.G. Absorbance, absorption coefficient, and apparent quantum yield: A comment on common ambiguity in the use of these optical concepts. Limnol. Oceanogr. 2002, 47, 1261-1267. [CrossRef]

40. Stedmon, C.A.; Markager, S.; Bro, R. Tracing dissolved organic matter in aquatic environments using a new approach to fluorescence spectroscopy. Mar. Chem. 2003, 82, 239-254. [CrossRef]

41. Lawaetz, A.J.; Stedmon, C.A. Fluorescence Intensity Calibration Using the Raman Scatter Peak of Water. Appl. Spectrosc. 2009, 63, 936-940. [CrossRef] [PubMed]

42. Wang, W.; Wang, S.; Jiang, X.; Zheng, B.; Zhao, L.; Zhang, B.; Chen, J. Differences in fluorescence characteristics and bioavailability of water-soluble organic matter (WSOM) in sediments and suspended solids in Lihu Lake, China. Environ. Sci. Pollut. Res. 2018, 25, 12648-12662. [CrossRef] [PubMed]

43. Stedmon, C.A.; Bro, R. Characterizing dissolved organic matter fluorescence with parallel factor analysis: A tutorial. Limnol. Oceanogr. Methods 2008, 6, 572-579. [CrossRef]

44. McKnight, D.M.; Boyer, E.W.; Westerhoff, P.K.; Doran, P.T.; Kulbe, T.; Andersen, D.T. Spectro fluorometric characterization of dissolved organic matter for indication of precursor organic material and aromaticity. Limnol. Oceanogr. 2001, 46, 38-48. [CrossRef]

45. Zhang, Y.; Liu, X.; Wang, M.; Qin, B. Compositional differences of chromophoric dissolved organic matter derived from phytoplankton and macrophytes. Org. Geochem. 2013, 55, 26-37. [CrossRef]

46. Song, K.; Wen, Z.; Jacinthe, P.-A.; Zhao, Y.; Du, J. Dissolved carbon and CDOM in lake ice and underlying waters along a salinity gradient in shallow lakes of Northeast China. J. Hydrol. 2019, 571, 545-558. [CrossRef]

47. Xie, H.; Aubry, C.; Bélanger, S.; Song, G. The dynamics of absorption coefficients of CDOM and particles in the St. Lawrence estuarine system: Biogeochemical and physical implications. Mar. Chem. 2012, 128, 44-56. [CrossRef]

48. Zhou, F.; Gao, X.; Song, J.; Chen, C.-T.A.; Yuan, H.; Xing, Q. Absorption properties of chromophoric dissolved organic matter (CDOM) in the East China Sea and the waters off eastern Taiwan. Cont. Shelf Res. 2018, 159, 12-23. [CrossRef]

49. Zhang, Y.; Yin, Y.; Feng, L.; Zhu, G.; Shi, Z.; Liu, X.; Zhang, Y. Characterizing chromophoric dissolved organic matter in Lake Tianmuhu and its catchment basin using excitation-emission matrix fluorescence and parallel factor analysis. Water Res. 2011, 45, 5110-5122. [CrossRef] [PubMed]

50. Zhou, Y.-Q.; Zhang, Y.; Niu, C.; Wang, M.-Z. Characterizing chromophoric dissolved organic matter (CDOM) in Lake Honghu, Lake Donghu and Lake Liangzihu using excitation-emission matrices (EEMs) fluorescence and parallel factor analysis (PARAFAC). Spectrosc. Spectr. Anal. 2013, 33, 3286-3292. [CrossRef]

51. Coble, P.G. Characterization of marine and terrestrial DOM in seawater using excitation-emission matrix spectroscopy. Mar. Chem. 1996, 51, 325-346. [CrossRef]

52. Wu, T.; Qin, B.; Brookes, J.D.; Yan, W.; Ji, X.; Feng, J. Spatial distribution of sediment nitrogen and phosphorus in Lake Taihu from a hydrodynamics-induced transport perspective. Sci. Total. Environ. 2019, 650, 1554-1565. [CrossRef]

53. Yao, S.C.; Xue, B. Nutrients and heavy metals in multi-cores from Zhushan Bay at Taihu Lake, the largest shallow lake in the Yangtze Delta, China. Quat. Int. 2010, 226, 23-28. [CrossRef]

54. Liu, J.J.; Lu, J.; Zhu, G.W.; Gao, M.Y.; Wen, L.; Yao, M.; Nie, Q. Occurrence characteristics of black patch events and their influencing factors in Lake Taihu during 2009 and 2017. J. Lake Sci. 2018, 30, 1196-1205. [CrossRef]

55. Miao, S.; Lyu, H.; Wang, Q.; Li, Y.; Wu, Z.; Du, C.; Xu, J.; Bi, S.; Mu, M.; Lei, S. Estimation of terrestrial humic-like substances in inland lakes based on the optical and fluorescence characteristics of chromophoric dissolved organic matter (CDOM) using OLCI images. Ecol. Indic. 2019, 101, 399-409. [CrossRef]

56. Huguet, A.; Vacher, L.; Relexans, S.; Saubusse, S.; Froidefond, J.; Parlanti, E. Properties of fluorescent dissolved organic matter in the Gironde Estuary. Org. Geochem. 2009, 40, 706-719. [CrossRef]

57. Sun, W.; Gong, X.L.; Chen, Y.; Zheng, W.J.; Li, Q.; Du, Y.X. Photochemical degradation of the algae-derived dissolved organic matter in Lake Taihu. J. Lake Sci. 2018, 30, 91-101. [CrossRef]

58. Shi, Q.; Feng, W.; Song, F.; Li, T.; Guo, W.; Wang, B.; Wang, H.; Wu, F. Photodegradation of algae and macrophyte-derived dissolved organic matter: A multi-method assessment of DOM transformation. Limnologica 2019, 77, 125683. [CrossRef] 
59. Du, Y.; Zhang, Y.; Chen, F.; Chang, Y.; Liu, Z. Photochemical reactivities of dissolved organic matter (DOM) in a sub-alpine lake revealed by EEM-PARAFAC: An insight into the fate of allochthonous DOM in alpine lakes affected by climate change. Sci. Total Environ. 2016, 568, 216-225. [CrossRef] [PubMed]

60. Song, F.; Wu, F.-C.; Feng, W.; Liu, S.; He, J.; Li, T.; Zhang, J.; Wu, A.; Amarasiriwardena, D.; Xing, B.; et al. Depth-dependent variations of dissolved organic matter composition and humification in a plateau lake using fluorescence spectroscopy. Chemosphere 2019, 225, 507-516. [CrossRef]

61. Jiang, T.; Chen, X.; Wang, D.; Liang, J.; Bai, W.; Zhang, C.; Wang, Q.; Wei, S. Dynamics of dissolved organic matter (DOM) in a typical inland lake of the Three Gorges Reservoir area: Fluorescent properties and their implications for dissolved mercury species. J. Environ. Manag. 2018, 206, 418-429. [CrossRef]

62. Devilbiss, S.E.; Zhou, Z.; Klump, J.V.; Guo, L. Spatiotemporal variations in the abundance and composition of bulk and chromophoric dissolved organic matter in seasonally hypoxia-influenced Green Bay, Lake Michigan, USA. Sci. Total Environ. 2016, 565, 742-757. [CrossRef]

63. Gu, Y.; Wu, Z.X.; Liu, M.L.; He, J.B.; Gao, Y.R.; Yu, Z.M. Temporal and spatial distribution of CDOM in the Xinanjiang Reservoir. J. Hydrol. 2013, 34, 14-17. [CrossRef]

64. Hao, Z.; Gao, Y.; Yang, T. Seasonal variation of DOM and associated stoichiometry for freshwater ecosystem in the subtropical watershed: Indicating the optimal C:N:P ratio. Ecol. Indic. 2017, 78, 37-47. [CrossRef]

65. Li, C.; Wu, S.; Dong, R. Dynamics of organic matter, nitrogen and phosphorus removal and their interactions in a tidal operated constructed wetland. J. Environ. Manag. 2015, 151, 310-316. [CrossRef]

66. Li, H.; Song, C.; Cao, X.-Y.; Zhou, Y.-Y. The phosphorus release pathways and their mechanisms driven by organic carbon and nitrogen in sediments of eutrophic shallow lakes. Sci. Total Environ. 2016, 572, 280-288. [CrossRef]

67. Du, Y.; Zhang, Q.; Liu, Z.; He, H.; Lürling, M.; Chen, M.; Zhang, Y. Composition of dissolved organic matter controls interactions with $\mathrm{La}$ and $\mathrm{Al}$ ions: Implications for phosphorus immobilization in eutrophic lakes. Environ. Pollut. 2019, 248, 36-47. [CrossRef] [PubMed]

68. Mbabazi, J.; Inoue, T.; Yokota, K.; Saga, M. Variability of particulate bioavailable phosphorus, particulate organic carbon and nitrogen in agricultural and urban rivers. J. Environ. Chem. Eng. 2019, 7, 103086. [CrossRef]

69. Coble, A.A.; Marcarelli, A.M.; Kane, E.S. Ammonium and glucose amendments stimulate dissolved organic matter mineralization in a Lake Superior tributary. J. Great Lakes Res. 2015, 41, 801-807. [CrossRef]

70. Feng, W.; Yang, F.; Zhang, C.; Liu, J.; Song, F.; Chen, H.; Zhu, Y.; Liu, S.; Giesy, J.P. Composition characterization and biotransformation of dissolved, particulate and algae organic phosphorus in eutrophic lakes. Environ. Pollut. 2020, 265, 114838. [CrossRef] [PubMed] 